\title{
Match-Making Programs in Turkish Tv Channels
}

\section{Pembe Tölük, Eastern Mediterranean University, TRNC \\ Bahire Efe Özad, Eastern Mediterranean University, TRNC}

\begin{abstract}
In the national Turkish television channels, recently a new program type called "Match making Programs" has appeared. These programs seek to attract women audience, particularly housewives who stay at home and keep the TV on during the hours when husbands are at work and children are at school. These programs target women audience and choose topics that would attract them. In a way, these programs stand as the indicators of the governments' policies in the sense put forth by Althusser as the state ideological apparatus. The present paper seeks to analyze audience's reactions to these programs that are mostly broadcasted during the day. These programs represent the reflection of Turkish women with the content chosen to satisfy their needs. The study in based on "Uses and Gratifications Theory" which takes the audience as active beings and use the media to satisfy their needs. For the study, focus group interviews have been conducted with a group of housewives who follow these programmes.
\end{abstract}

Keywords: women audience, state ideological apparatus, Uses and Gratifications Theory, Turkish TV channels, women's programs 


\section{Introduction}

Women's programs have become very popular in recent years in the Turkish TV channels. The density of women audience during the day time led to the emergence of a program type called "Women's Program" and the present paper seeks to explore the reasons why these programs are watched by women. This new genre, "Women's Programs", is directed towards women and is divided into two broad categories which are match-making programs and other women programs. Match-making programs seek to help people find partners and get married. The other women's programs include mostly cooking, handcrafts, health information. For this study, the Uses and Gratifications Theory is found useful to grasp the motives for the reasons of women's watching match-making TV programs. In this study, the match-making programs are investigated and Turkish women audience's interests are evaluated through focus group interviews with nine women.

\section{The Relationship between the Uses and Gratifications Theory and Turkish Women's}

\section{Audiences}

Match-making programs have started to occupy an important place in the Turkish TV channels from the 2007 onwards. Hence, these programs draw our attention to the presentation of marriage in the society and understanding women's and men's role in that society (Nüfusçu and Y1lmaz, 2012, p.27). When looking at the match-making programs in the Turkish national channels, Esra Erol'la Evlen Benimle in ATV channel, Zuhal Topal'la Izdivac in Fox TV channel, Evleneceksen Gel in Star TV channel and Kismetse Olur in Kanal D stand out as the most popular programs. These programs offer an organized introduction and meeting ceremony of the participants in the TV and a form an environment that participants feel themselves as secured and trusted. In other words, producers, speakers of these programs and workers of the programs concentrate on the participants' comforts; the reasons may be all these will return themselves as more rating and advertisements.

When concentrating on the Turkish women audience' preference of the TV channels, the most popular channels for women can be listed as; firstly, Star TV (21.7\%); secondly, Kanal D (19.2\%); thirdly, ATV (17.5\%); on the other hand, women's less preferred channels are; firstly, NTV (1.7\%); secondly, CNN (2.9\%); thirdly, TRT (5.8\%) (Meder and Çiçek, 2012, p.17). From this perspective, the top three channels which are Star TV, Kanal D and ATV 
have match-making programs in their program; however, NTV and CNN are news channels and therefore they have not got match-making programs.

Uses and Gratifications Theory asserts that people use media to gratify their needs and to attain their goals (Blumler and Katz, 1974, p.21). Accordingly, Uses and Gratifications Theory consists mainly of five assumptions according to Katz, Gurevtich and Haas (1973). Firstly, the selections and uses of the media by the audience are goal-directed, purposeful and motivation oriented. Hence, this theory suggests that media are functional and use of media have implications for societies. Secondly, individuals select media instruments, so, people use media to gratify their needs or interests (Katz, Gurevtich and Haas, 1973). Thirdly, audience's tendency is composed of their environments and personal relations. Based on these expectations, audience choose media and media content. In this regard, people filter media messages according to their characteristics, social groups and relationships. Fourthly, media gratify our social and psychological desires. Fifthly, according to Rosengren, (1974) A. M. Rubin and Windahl (1986), İndividuals have their own initiatives; therefore, they are effective in the media use. In this context, media may have an influence on people's features or political, social, cultural and economic structure of society (Bryant and Zillmann, 2008, p.527-528).

The root of Uses and Gratifications Theory goes back to the time for the Second World War. Herzog (1944) made a research about why women listen to the radio soap operas and what their main motivations and gratifications are that has taken from soap operas by women. Because of that, she conducted 100 interviews for analysing this subject and results were interesting. Women pointed out that they were informed, entertained, obtained knowledge for themselves and others, and obtained the opportunity for thinking (Curran, 1996; Williams 2003, p.177). In a nutshell, women preferred radio soap operas based on these reasons. More importantly, Uses and Gratifications Theory is fundamental for identifying people's motivations and desires in the media sector and selections. Uses and Gratifications Theory is interested in the position of individuals for grasping and interpreting media messages (Wiliams, 2003, p.178). Therefore, Uses and Gratifications Theory underlies the audiences' capability for selecting, interpreting and how they satisfy their own needs when watching or using the media instruments. 
According to A. M. Rubin (2009), Uses and Gratifications Theory is based on psychological communication view in explaining media effects. In this regard, the social and psychological features are essential for guiding, filtering and mediating the media (Cortese and Rubin, 2010, p.90). According to Rubin (1993), the main idea of Uses and Gratifications Theory depends on the understanding of the audiences' motivations and behaviours in the media use (Brown, Lauricella, Douai and Zaidi, 2012, p.49). To sum up, Katz, Blumler and Gurevitch emphasized the major goals of Uses and Gratifications Theory. They argued that this theory clarifies how people use media to gratify their needs, to understand motives for media behaviours, to know functions and results of needs, motives and behaviour (Alan Rubin, 2008, p.527). Uses and Gratifications Theory concentrates on the audience's attention to the mass communication process and it differentiates active uses from passive uses in the case of intentionally selection (Baran and Davis, 2009, pp.231-232).

Media have great impact on the formation of social reality, production of sexual roles in the society and TV includes both visual and auditory aspects and thus media have an influence on people's knowledge, culture, and entertainment needs (Aziz, 1982; Göksel, (1993 in Meder and Çiçek, 2011, p.70). From this perspective, media instruments expand the ideology, opinion, attitude and culture. More notably, the ideology and state ideological apparatuses are important concepts put by Althusser. According to Althusser, the state has got ideological apparatuses that interplay with social practices and ideology always affects social life (Tekinalp and Uzun, 2009, p.180). According to him, the state's pressure apparatuses are divided into two parts which are state pressure apparatuses and state ideological apparatus. The state pressure apparatus are the military, police, judiciary, and governments' executive power. On the other hand, the state ideological apparatuses are school, religion, family and mass media instruments, Mass media instruments are producing of the ideology and distributing the ideology. In this regard, the state ideological apparatuses work together with harmony (Güngör, 2013, p.262). Additionally, the ideology is neutralized with the help of the state ideological apparatuses and reproduces continuously (Kaya, 2013, p.83). Althusser concentrates on the ideological apparatuses and its effects on the formation of people's opinion. Althusser claims that the production and reproduction of ideology is based on the functional apparatuses which are also the state ideological apparatuses. This is because state has power and it handles that power through some agencies. The intensity of these programs indicates the wishes of the governments that use the media as disseminating their ideology. In 
this context, the match-making programs reinforce traditional society's sexual roles and it offers how the sex roles for men and women' would be shaped with the help of TV. More notably, the match-making programs strengthen the transfer of ideology and the dominant ideology occurs more in the marriage practices (Kaya, 2013, p.81). From this point of view, the match-making programs prevail patriarchy that exists in Turkish traditions, in other words, the match-making programs reinforce target reality and ideology.

The match-making programs are the most interesting content among other women's programs. Additionally, similar programs are found in other countries yet ages and the criteria of the candidates in the Turkish TV channels are completely different. In the West, such programs are done with young people. But in the Turkish channels, there is a variety of age of participants. In the West, participants are well-groomed yet in Turkey both beautiful and handsome.

Like all other media formats, format of the match-making programs represent mediated reality. In other words, these are not simple blind-date type programs but programs where the content is pre-arranged. That is to say, both the main characters and audience in the studio act. This is because the participants' questions and other participants' comments are based on mostly private issues. The main criteria for selecting a spouse are based on materialism such as having a car, house and money, not having a former marriage, not having children and to be beautiful or handsome. In addition to these, match-making programs stand out with the masculinity and femininity implications (Meder and Çiçek, 2011, p.77). With this regard, match-making programs are based on mediated reality and thus they set the scene for the audience while introducing to the prospective partners and choosing their partners. In other words, there are interactive communications among the audience and also they invite comments through telephone connections.

Another important issue is that match-making programs ignore the right of individual for keeping their privates lives for the rating and manipulates society accordingly (Polat and Karsl1, 2012, p.35). 
From this point of view, this research has concentrated on the understanding of the Turkish Cypriots housewives' motives and behaviours towards the match-making programs through the assumptions put forth by Uses and Gratifications Theory.

In this study, the main motives and reasons of women audiences' interests in match-making programs in Turkish TV channels are examined. The present study is based on 3 Focus Group interviews conducted with housewives.

\section{Methodology}

This study is based on qualitative research methodology. It is based on ethnographic approach. The present study has been conducted in the natural settings of the participants- at their homes. Data have been collected through three focus group interviews. Three focus group interviews have been conducted in their houses during their coffee parties. Data have been analyzed thematically.

Each focus group is composed of 3 women audience. Focus group interviews have been shown preferences for conversations and discussion about these programs and providing opportunities for women to reflect their ideas easily in a more relaxed and friendly environment. This research has been conducted in April, 2016 and interviews conducted face to face by the researchers at participants' homes.

The questions posed in the focus groups were related mainly to the nine themes given below:

1. How many hours do you watch TV?

2. Which channels do you watch mostly?

3. With whom do you watch?

4. Which programs do you watch?

5. Why do you watch these programs? Such as marriage?

6. What do you learn from these programs?

7. Why do you watch these programs frequently?

8. Do you think these TV figures are sincere?

9. What is the TV for you? 
10. According to your ideas, is TV popular for you although new improvements in Internet and smart phones applications?

11.

In each Focus Group, 3 people participated. For ethical reasons, the initial letters of the women participants' names are mentioned in the paper. In the first Focus Group, the participants are M, I and A; the second Focus Group, the participants are S, H and F; and in the third Focus Group; the participants are E, S and N.

\section{Analysis of Findings}

The study's aim is to find out women audience's attitude and the rationale for their interested in match-making programs. When focusing on the themes about the TV, they have intense relationship with TV because they are housewives and the TV is their best friend throughout the day. The first theme was "How many hours do you watch TV?" The aim of this question was to learn the duration of time spent by the Turkish Cypriots housewives' on TV; this indicates women's interests in the TV.

To the first question which was about the time they spend watching TV, Focus Group 1's participants answered around 3-5 hours whereas Focus Group 2' participants replied that it changes from 2 to 6 hours but the participant 3 said she watched the TV all day. The reason is probably because she is around 80 years old and she cannot do housework or else anymore. In this context, Focus Group 3 answered duration of watching TV is between 2-9 hours. These results clearly point out that Turkish housewives as the audience prefer to watch TV during the day and they devote their times willingly.

The second theme was "Which channels do you watch mostly?" The Focus Group 1's participants maintained that the main channels they watched were Kanal D, ATV, Fox and TV 8, Focus Group 2 said Star TV, ATV, Kanal 7 and one participant said Ada TV which is a local Cypriot channel. On the other hand, Focus Group 3 answered Fox TV, ATV, Star, Show TV, TV 8 and news channels. As it is shown, they prefer to see the main TV channels to watch that these channels have broad programs options. For example, Müge Anlı's reality show in ATV is an informative program about crimes and finding the guilty. In other words, it is real and it offers real events to them and women may be informed about the serious issues. Also, they have a preference to watch competition programs like Survivor in TV 8. 
The third theme was "With whom do you watch?" Focus Group 1's participants mostly said with their families, husband and also alone; however, Focus Group 2's participants answered differently. They mentioned they watched the TV with their grandmothers and grandchildren. Only participant 3 watched with her husband at home. When looking at the Focus Group 3's participants replied that they watched alone and with their family. According to their answers, participants frequently watched TV alone. This is because; they are alone during the day and watched the TV with their husbands at night. This means that Turkish housewives can afford the time to watch TV with their families and husbands which indicates their willingness to watch the TV and also show that they are not bored from TV.

The fourth theme was that "Which programs do you watch?" The aim is to learn Turkish housewives' favourite programs. In line with this, Focus Group 1's participants said generally serials, news, Müge Anll reality show, cooking programs and match-making programs especially Klsmetse Olur in Kanal D. Focus Group 2's participants replied generally in the same way as the Focus Group 1's participants. They mentioned that they watched serials, cooking programs, women and match-making programs but one participant added health programs according to her interest in this issue. On the other hand, Focus Group 3's participants answered different from Focus Groups 1 and 2's participants. Focus Group 3's participants said serials and competition programs but only one participant preferred to see women programs and match-making programs.

The fifth theme was that "Why do you watch these programs?" This is a significant question for analyzing the reasons and their satisfaction about women and match-making programs. More importantly, the result was very interesting. Almost all Focus Groups' participants said that they watched women programs only for spending time. However, Müge Anlı reality show is different in this sense because women expressed they are more aware about dangerous and crook events around their environment and they became more conscious. Similarly, they liked to watch serials and health programs for their satisfaction because when they watched serials, they left their problems behind and health programs offer information to them.

The sixth theme was that "What do you learn from these programs?" The aim of this question is to learn what the audiences' are gaining from these programs. The participants generally said nothing in Focus Group 1 but participant 3 answered differently from other participants. 
She points out that older women do not prefer to marry with poor men and these kinds of people are not sincere for her. In this regard, she is also interested in fashion programs such as "Işste Benim Stilim" because she may learn more designs and dressing-well form these programs. Focus Group 2's participants answered this question mostly learn how to cook differently, learns how to cook healthy food and diet but match-making programs are not real for them, they consider these programs as fake mediated. Also, the participant 3 added that sometimes she may learn how to solve her problems about some issues. However, Focus Group 3 replied this question remarkably because participants 1 and 2 answered that they learned nothing. The participant 3 points out that she learns how to commit crimes and crime results. Also match-making programs help them understand women's perceptions about marriage and she enjoys herself. From these results, it can be said that women learn nothing from match-making programs but they watch in order to enjoy themselves. Also, they expressed that women's programs offer recipes for healthy food so they learn these from women's programs.

When concentrating on the seventh theme "Why do you watch these programs frequently?" Focus Group 1 and 2's all participants answered this as to spend time. Participants 1 and 2 of the second focus group added that they also liked these women's programs but not matchmaking programs. On the other hand, Focus Group 3's participants answered to spend time and had nothing to do but the participant 2 said that for relaxing, when she watches competition programs, unlike match-making programs they are fake for her.

In line with this, the eight theme "Do you think these TV figures are sincere?" Focus Group 1's participants said "no", but Focus Group 2 participants said "yes". Participant 3 added in the match-making programs are partly real and partly are not real for me. On the other hand, Focus Group 3's participants' answered different from other 2 groups. The participant 1 said that figures do not seem to me as real but "Esra Erol" match-making programs in ATV seems real; others come only for money. The participant 2 said that have no interest so no comment. However, the participant 3 answered partly these programs are real.

The ninth theme was "What is the TV for you?". The Focus Group 1's participants said that entertainment, a friend and a voice at home. However, Focus group 2's participants said it was like a friend for them, others said that habit means a kind of addiction for them. On the 
other hand, the Focus group 3' participants said that generally the TV was like a voice, like a friend but the participant 3 answered that by this way time passes quickly at home.

The last theme was that "According to your ideas, is TV popular for you although new improvements in Internet and smart phones applications?" That is the critical question to grasp the importance of TV for Turkish housewives. The Focus Group 1's participants said "yes" and it is indispensable. The Focus Group 2's participants answered parallel to Focus Group 1 and said definitely "yes". On the other hand, Focus Group 3's participants answered "yes" and the participant 2 added that TV is more easily accessible when compared to the Internet because older women may not know how to use the internet.

\section{Conclusion}

There are real discussions about match-making programs in the Turkish press currently. According to Armağan Çağlayan's interview about match-making programs, the matchmaking programs are really edited. Some producers' promise to participants that they will be famous if they attended to these programs (http://t24.com.tr/haber/izdivac-programlarininpsikoterapisti-olaylar-kurgu-ve-cast,327388). With this regard, there are complaints about match-making programs to the RTUK (The Radio and TV Supreme Council) and most of them come from women. This reason is based on violation of privacy, marriage related with materiality and participants are criticized with their appearance and are threat to the privacy and honor of people (http://www.hurriyet.com.tr/evlendirme-programlari-rtukte-masayayatirildi-40056769). Another important criticism points out that these match-making programs spoil the social structure. These programs harm the family concept' and children are affected psychologically and mentally from these programs because they do not reflect the reality and some issues are publicized so there is no privacy among people (http://www.manisamanset.gen.tr/1716-Makale-program-ve-diziler-toplum-yapisini-bozuyor). From this point, everyone has the right to talk about participants' privacy and society. More importantly, the audiences' life publicized and other audiences or TV audiences take an actively part together with criticism or sometimes blaming them as not liking anyone or preferring money to love.

According to the Focus Group interview results, Turkish Cypriot participants as housewives mostly watch match-making programs. They found these programs as fake and not sincere. 
They watch these programs for consuming time. In this context, Turkish Cypriot housewives watch the match-making programs because of the lack of other entertainment programs. They are forced to watch these programs involuntarily. Additionally, participants are entertained when they watch these programs because they escape from their daily problems by watching these programs. From this view, Turkish Cypriot housewives watch match-making programs for both the lack of other entertainment programs and in order to divert from their problems. The other significant finding is that Turkish Cypriot housewives found Müge Anl reality show in ATV very useful because they maintained that learn crimes and potential dangers, so they become more aware about them. However, they believed that the match-making programs are fake and unconvincing. In this regard, Turkish Cypriot housewives like to watch health programs and cooking programs because they learn more about healthy lifestyles and recipes. In addition to these, some participants expressed that they like fashion programs that give them information about dressing codes and how to get dressed in different occasions. Another interesting result is that almost all participants clearly pointed out that TV has an important place in their lives such as entertainment instrument, friends, habit or voice their homes. More importantly, all participants stressed that TV is indispensable for them despite technological instruments such as smart phones and the Internet. From this point of view, TV and its program contents are influential still for Turkish Cypriot housewives and they think that TV is like a friend for them during the day, hence, it can be argued that Turkish Cypriot housewives welcomes whatever the TV offers even if it presented mediated reality.

On the other hand, the main problem of these programs is that private sphere is opened to the public sphere. Thus, match-making programs damage individuals' private lives and society talks about them and make advice to match-making programs' participants. In this context, private sphere becomes public sphere and it really destructs the social order and social structure. To eliminate this negative issue, the producers of these programs need to focus on ethical issues more. 


\section{References:}

Baran, S. J. and Davis, D. K., (2009) Mass Communication Theory, Boston-USA: Wadsworth Cengage Learning, (Fifth Edition).

Blumler, J. G. and Katz, E. (1974) The Uses of Mass Communications: Current Perspectives on Gratifications Research, Beverly Hills: SAGE Publications.

Alan Rubin "The Uses and Gratifications Perspective of Media Effects" in the book of Bryant, J. and Zillmann,D. (2008) Media Effects: Advances in Theory and Research, Mahwah: New Jersey: Lawrance Erlbaum Associates.

Brown, D., Lauricella, S., Douai, A., and Zaidi, A., (2012) Consuming Television Crime Drama: A Uses and Gratifications Approach, American Communication Journal, 14:1, pp.47-60.

Cortese, J. and Rubin, A. M. (2010) Uses and Gratifications of Television Home Shopping, Atlantic Journal of Communication 18:2, pp.89-109.

Güngör, N. (2013) İletişim Kuramlar, Yaklaşımlar, Ankara: Siyasal Kitabevi.

Kaya, T. (2013) Televizyonda Yayınlanan İzdivaç Programlarında Toplumsal Cinsiyetin Temsili, Kadın Araştırmaları Dergisi 13, pp.81-110.

Meder, M. and Çiçek, Z. (2012) Mahremiyet Anlayışının Yerinden Edilmesinin Aracı Olarak Kadın Programlarının Türsel ve Söylemsel Analizi: Denizli Örneği, Pamukkale Üniversitesi, Sosyal Bilimler Enstitisu Dergisi 12, pp.9-28.

Meder, M. and Çiçek, Z. (2011) Özel Hayatın Kamusal Alanda Tartışılması: Kadın Programları Üzerine Sosyolojik Bir Değerlendirme, Pamukkale Üniversitesi, Sosyal Bilimler Enstitisu Dergisi, 9, pp.69-80.

Nüfusçu, Aytemur, A., (2012) Evlilik Pratiklerinin Dönüşüm/Yeniden Üretim Sürecinde Evlendirme Programları, Galatasaray Üniversitesi, İletişim Dergisi, pp.23-48.

Polat, F. and Karslı, B., (2012) Evlilğe İlişkin Türk Televizyon Programlarının Sosyolojik Analizi, EKEV Akademi Dergisi, 16:51, pp.31-44.

Tekinalp, S. And Uzun, R., (2009) İletisim Araştırmaları ve Kuramları, İstanbul: Beta Press. Williams, K. (2003) Understanding Media Theory, Great Britain: Oxford University Press. http://t24.com.tr/haber/izdivac-programlarinin-psikoterapisti-olaylar-kurgu-ve-cast,327388 http://www.hurriyet.com.tr/evlendirme-programlari-rtukte-masaya-yatirildi-40056769 http://www.manisamanset.gen.tr/1716-Makale-program-ve-diziler-toplum-yapisini-bozuyor 